\title{
A HYBRID MCDM MODEL ENCOMPASSING AHP AND COPRAS-G METHODS FOR SELECTING COMPANY SUPPLIER IN IRAN
}

\author{
Sarfaraz Hashemkhani Zolfani ${ }^{1,2}$, I-Shuo Chen ${ }^{3}$, Nahid Rezaeiniya ${ }^{4}$, \\ Jolanta Tamošaitien $\dot{e}^{5}$
}

${ }^{1}$ Research Institute of Internet and Intelligent Technologies, Vilnius Gediminas Technical University,

Sauletekio al. 11, LT-10223 Vilnius, Lithuania

${ }^{2}$ Shomal University, P.O. Box 731, Amol, Mazandaran, Iran

${ }^{3}$ School of Business (Research) Trinity College Dublin, College Green, Dublin 2, Ireland

${ }^{4}$ Alghadir Institute of Higher Education P.O. Box 5166898691, Tabriz, Azarbaijan Sharghi, Iran

${ }^{5}$ Department of Construction Technology and Management, Vilnius Gediminas Technical University,

Sauletekio al. 11, LT-10223 Vilnius, Lithuania

E-mails: ${ }^{1,2}$ sa.hashemkhani@vgtu.lt; ${ }^{3}$ ch655244@yahoo.com; ${ }^{4}$ rezaeiniya_121@yahoo.com;

5jolanta.tamosaitiene@vgtu.lt (correspondingauthor)

Received 12 February 2012; accepted 03 July 2012

\begin{abstract}
This paper is aimed at utilizing a hybrid multi-criteria decision making (MCDM) model for selecting a supplier. First, eight evaluation criteria, including cost, quality, distance, delivery reliability, reputation, technology level, compatibility and development ability are identified. The Analytic Hierarchical Process (AHP) is initially used for calculating the weight of each criterion. The COmplex PRoportional ASsessment of alternatives to Grey relations (COPRAS-G method) is adopted for ranking and selecting suppliers. In order to illustrate the functional ability of the developed model, Kalleh Company is chosen as a case study and can be used as a pattern for supplier selection and future researches.
\end{abstract}

Keywords: MCDM, AHP, COPRAS-G, hybrid model, selection, construction, supply chain.

Reference to this paper should be made as follows: Hashemkhani Zolfani, S.; Chen, I-S.; Rezaeiniya, N.; Tamošaitienè, J. 2012. A hybrid MCDM model encompassing AHP and COPRAS-G methods for selecting company supplier in Iran, Technological and Economic Development of Economy 18(3): 529-543.

JEL Classification: C44, C51. 


\section{Introduction}

Due to global intensive competition, many companies prioritize quick and precise responses to customers' various demands improving their supply chain management (SCM). Many manufacturers seek to collaborate with their suppliers in order to upgrade their management performance and competitiveness. Thus, decisions on supplier selection are an important component of production and logistics management for plenty of firms in the process of SCM (Xia, Wu 2007). In addition, selecting suitable suppliers significantly reduces material purchasing cost, improves the competitiveness of businesses, increases flexibility and product quality and helps with speeding up the process of material purchasing. This is why many experts believe that supplier selection is the most important activity in a purchasing department.

The term SCM was first used in the 1980s and as such is a relatively new discipline within a management theory about tools and concepts still being developed (Lummus, Vokurka 1999). Many definitions have been used to explain SCM: an integrating philosophy to manage the total flow of a distribution channel from supplier to ultimate customer (Ellram, Cooper 1990), the management of upstream and downstream relationships with suppliers and customers to deliver a superior customer value at less cost to the supply chain as a whole (Christopher 1998), etc. The subject is multi-disciplinary and has its origins in a number of fields, including purchasing, logistics and operations.

Given its multi-disciplinary nature, there is a requirement for cross-boundary management (Lummus, Vokurka 1999). Whichever definition is applied in today's dynamic business environments, cost-effective SCM is a matter of survival as purchased goods and services account for up to 80 percent of sales revenue (Quayle 2003). When building the idea of SCM as a strategic shift in company's governing principles, SCM must be seen as professional practice and the one that is at the heart of a corporate strategy of the organization (Quayle 2003). The importance of effective SCM can also be seen in the ability of an organization to gain competitive advantage.

Owing to the fact that external pressure from consumers requires organizations to focus on better quality, lower prices, shorter lead times and greater cost efficiencies to achieve the above requirements, there is growing recognition of the need to externalize SCM and take a holistic view focusing on relationships in order to secure more profitable outcomes for all parties in the chain (Christopher 1998). Therefore, the selection of the best supplier for such relationships is becoming a critical issue for most organizations in each industry alike.

Supplier selection is a multiple criteria decision-making (MCDM) problem affected by several conflicting factors. Consequently, a purchasing manager must analyze trade-off between several criteria. MCDM techniques support decision-makers (DMs) in evaluating a set of alternatives (Amid, Ghodsypour 2006). The problem of supplier selection in a supply chain system is a group decision based on multiple criteria. Besides, purchase managers should especially know the most appropriate method and then use it for selecting the right supplier. It is because the right supplier could work with companies closely and offer the sustained company competitive advantages such as low purchase prices, on time products, high product quality and customer satisfaction. Since there is a lack of studies related to such 
topic in Iran, supplier selection is therefore one of the most important problems encountered by a number of companies in Iran due to the fact that most of those have currently failed to benefit by selecting their suppliers.

Quite a few traditional MCDM methods such as COmplex PRoportional ASsessment COPRAS (Zavadskas, Kaklauskas 1996), AHP (Saaty 1990), ARAS (Zavadskas, Turskis 2010; Zavadskas et al. 2010b), etc. can be introduced. Specifically, AHP is initially used for calculating the weight of each criterion and the COPRAS-G method is employed for ranking and selecting the target suppliers. AHP is a tool for complex problems where both qualitative and quantitative aspects need to be considered. AHP could reduce the risk of making the wrong decision through breaking down the decision problem into a hierarchy of more easily comprehended sub-problems. It utilizes the consistency index and the random index to verify the consistency of the comparison matrix (Saaty 1990). Therefore, AHP is a useful method for weighting and ranking alternatives. COPRAS-G (Zavadskas et al. 2008a) and ARAS-G (Turskis, Zavadskas 2010) methods are based on the Grey system theory and Grey relational analysis. The advantages of that are as follows: involves simple calculations and requires a smaller number of samples; a typical distribution of samples is not required; quantified outcomes from grey relational grade do not result in contradictory conclusions to qualitative analysis; the Grey relational grade model is a transfer functional model effective in dealing with discrete data (Deng 1982). Both methods, including AHP (Liberatore, Nydick 2008; Sivilevicius 2011a, b) and COPRAS-G (Zavadskas et al. 2008b; Datta et al. 2009; Hashemkhani Zolfani et al. 2011) have been applied to many management decision-making situations. For supplier selection, this research uses a hybrid MCDM model encompassing AHP and the COmplex PRoportional ASsessment of alternatives to Grey relations (COPRAS-G method).

\section{The problem of selecting suppliers to construction}

At present, the study of supplier selection has been a very popular question for discussions on the worldwide basis. A number of evaluation criteria that could significantly impact the successful selection of suppliers have been proposed. The main factors to consider include time (T), quality $(\mathrm{Q})$, cost $(\mathrm{C})$ and service $(\mathrm{S})$ and are the key factors for getting success in the process of choosing suppliers. The cost of the construction project could be broadly divided into three major groups, namely materials, labour and overhead. In addition, the cost of the labour is generally governed by the availability of workers within proximity; only construction materials can provide the greatest flexibility in seeking lower cost for construction companies. The model of supplier selection must include two general skills: effective and efficient. The "best" suppliers take a proposal concerning the right cost in the right quantity with the right quality and at the right time has a significant effect on business success in property developers.

Furthermore, Shuyong and Rongqiu (1998) maintained that supplier evaluation should rely on the following attributes: quality, delivery period, batch flexibility, the balance between the delivery period and price, the balance between the price and batch, variety, etc. Shihua and Xubin (2002) developed an integrated evaluating attribute system for selecting co-partners under the circumstances of supply chain management and generalized four main factors 
that could affect co-partner selection: outstanding achievement of an enterprise, operation structure and throughput, quality system and enterprise environment. Lijuan (2002) proposed that criteria for supplier selection were composed of nine evaluating attributes: product quality, product price, after service, distance, technological level, supply capability, economic revenue, delivery and market influence. In construction industry, suppliers offer heavy equipment and machinery, labour, building materials, service expertise, etc. (Florez-Lopez 2007; Ustun, Demirtas 2008; Lam et al. 2010). Due to the nature of construction industry, such specialization of work and the fragmentation of the overall process taking into account the coordination of the procurement process of supply chain members becomes a challenging task. Therefore, an important point is the selection of the right supplier in each life cycle of construction building (see Figure 1).

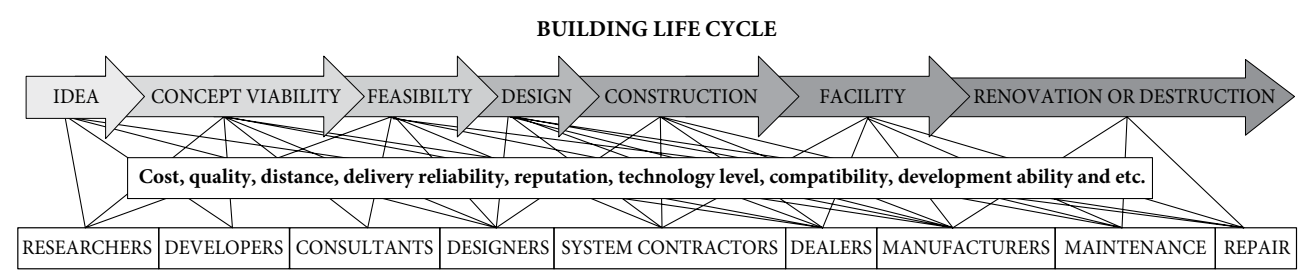

SUPPLIER TYPES

Fig. 1. Supplier types of building life cycle

The study has summarized the latest studies on supplier selection and pointed out eight evaluation criteria: cost, quality, distance, delivery reliability, reputation, technology level, compatibility and development ability.

\section{Model for selecting suppliers based on AHP and COPRAS-G methods}

The problem of supporting supplier selection have been analyzed by a number of authors. Also, there are numerous evaluation methods for selecting the required suppliers. Additionally, Xu et al. (2009) put forward the rough data envelopment analysis model (DEA) to deal with the problem of supplier selection. Furthermore, Shiromaru (2000) adopted the fuzzy programming approach to dealing with the problems of fuzzy goals in the process of supplier selection and used inheritance arithmetic to request the solution. Moreover, Zhu (2004) simplified DEA through the game model of swapper twain stages and conducted efficiency interior to evaluate suppliers. Shihua and Xubin (2002) published a Grey relating model to settle supplier evaluation on the weight of evaluation criteria. Numerous researches concentrate on the problem of selecting supplier using different methods (Baležentis, A., Baležentis, T. 2011). Therefore, the aim of this study is to overcome this deficiency referring to the oldest and most famous company producing disposable containers in Iran as a case of a hybrid MCDM model encompassing AHP and COPRAS-G methods.

AHP not only helps with the analysis of arriving at the best decision but also provides a clear rational orientation to the made choices, involves the principles of decomposition, 
pair-wise comparisons and the generation and synthesis of priority vectors. COPRAS-G is a distinct measure that combines qualitative and quantitative factors such as trust and feature state (Madhuri, Chandulal 2010). It assumes the direct and proportional dependence of the significance and utility degree of investigated versions on a system of attributes adequately describing the alternatives, values and weights of the attributes (Zavadskas et al. 2008a, b, 2009, 2010a). Hence, AHP and COPRAS-G combined are useful and flexible MCDM methods for discovering the aim of this study.

\section{Hybrid MCDM model}

The proposed hybrid MCDM model for problem solving consists of AHP and COPRAS-G methods. Saaty proposed AHP as a multiple criteria decision-making method applied to overcoming problems under uncertain conditions. The goal of COPRAS-G method finds the rational solution by applying utility degree of each alternative using criterion values expressed in intervals. Proposed hybrid MCDM model to pursue the decision-maker find the rational solution. Hierarchy appraisal and decomposition of the problem separation makes it possible to describe the problem. The goal of the proposed model achieve a more accurate solution. The elements of hierarchy can relate to any aspect of the decision problem such as tangible or intangible, carefully measured or roughly estimated, well or poorly understood, i.e. anything that applies to the decision at hand. It has been well utilized in several fields (Saaty 1990) that require choosing alternatives and weight exploration of evaluation indices like business (Angelou, Economides 2009), industry (Chen, Wang 2010) and healthcare (Liberatore, Nydick 2008).

Decision analysis is concerned with the situation when a decision-maker has to choose among several alternatives considering a particular set of evaluation criteria. For this reason, the COPRAS-G method can be applied. In 1982, Deng developed the Grey system theory. The idea of the COPRAS-G method, along with criterion values expressed in the intervals, is based on real conditions for decision making and applications for the Grey system theory that uses a stepwise ranking and evaluating procedure of alternatives in terms of significance and utility degree (Zavadskas et al. 2008b). Research on the selection model of construction supplier is based on grey relevancy presented by Wang and Guo (2007) and fuzzy multiple criteria introduced by Wang (2008). In this case, the hybrid MCDM model encompassing AHP and COPRAS-G methods for reaching a solution to the problem is presented in Figure 2.

In the past, 13 major conditions were discovered to be well suited to the utilization of AHP and included setting priorities, generating a set of alternatives, choosing the best alternatives for the policy, determining requirements, allocating resources, predicting outcomes, measuring performance, designing systems, ensuring system stability, optimization, planning, resolving conflict and risk assessment (Saaty 1990). Construction environment is risky, and therefore the risk of construction was analyzed by Zavadskas et al. (2010a). The calculation of AHP is the adopted ratio scale for developing a pair-wise comparison matrix. Ratio values from 1 to 9 are given to each sub-scale and presented in Table 1, which can be typically categorized into five sub-scales based on different levels of importance. There are still four sub-scales above the five major sub-scales making a total of nine sub-scales. 


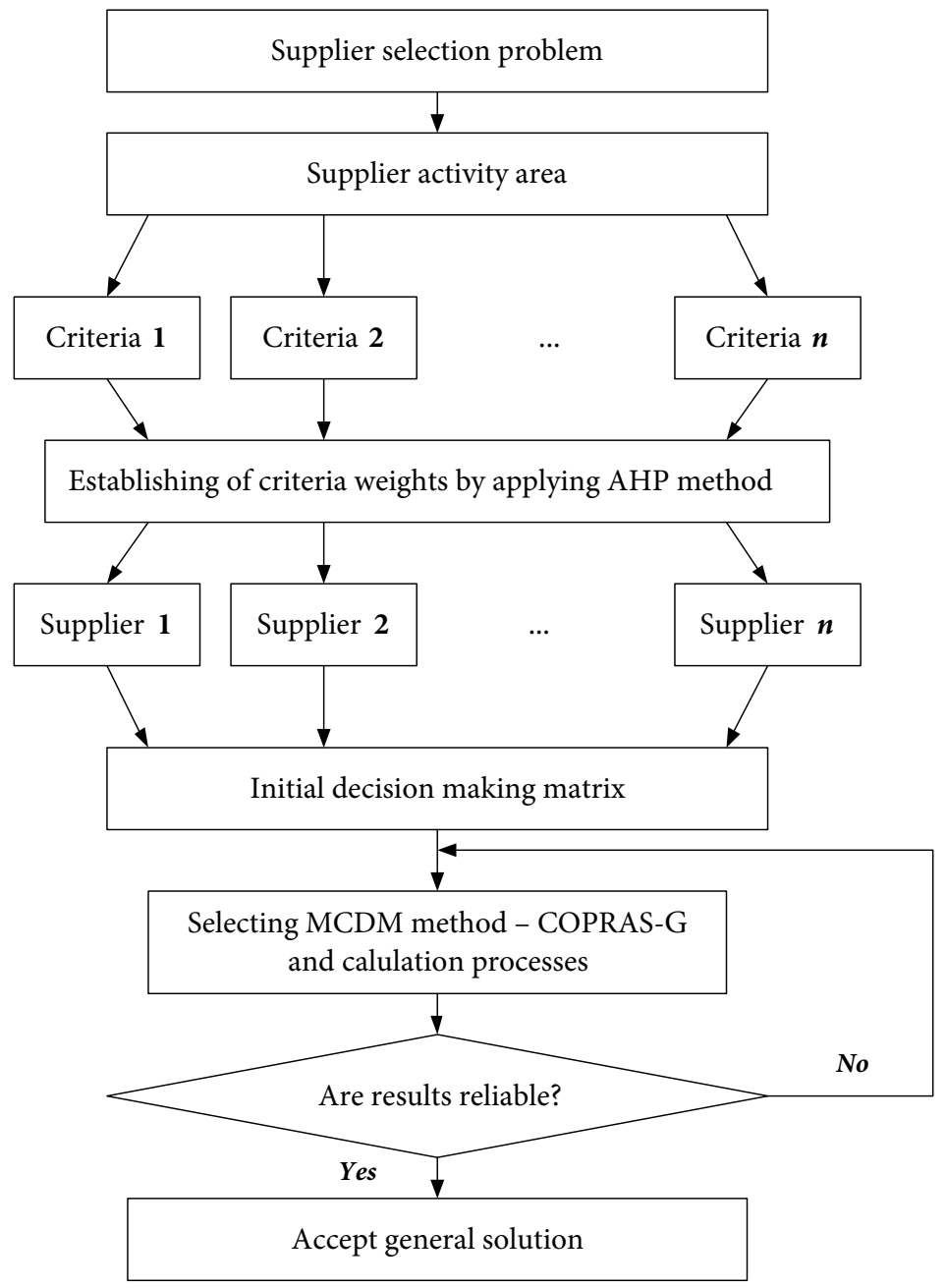

Fig. 2. The proposed hybrid model MCDM encompassing AHP and COPRAS-G methods

Table 1. The ratio scale and definition of AHP (Saaty 1990)

\begin{tabular}{cl}
\hline Intensity of importance & \multicolumn{1}{c}{ Definition } \\
\hline 1 & Equal importance \\
\hline 3 & Somewhat more important \\
\hline 5 & Much more important \\
\hline 7 & Very much more important \\
\hline 9 & Absolutely more important \\
\hline $2,4,6,8$ & Intermediate values \\
\hline
\end{tabular}


A review of recent applications for AHP, COPRAS and COPRAS-G methods is presented in Table 2.

Table 2. Recent applications for AHP, COPRAS and COPRAS-G

\begin{tabular}{lll}
\hline MCDM method & \multicolumn{1}{c}{ Reference } & \multicolumn{1}{c}{ Considered problem } \\
\hline \multirow{2}{*}{ AHP } & Medineckiene et al. (2010) & Sustainable construction \\
\cline { 2 - 3 } & Podvezko et al. (2010) & Evaluation of contracts \\
\cline { 2 - 3 } & Sivilevicius (2011a) & Modelling transport system \\
\cline { 2 - 3 } & Sivilevicius (2011b) & Quality of technology \\
\cline { 2 - 3 } & Fouladgar et al. (2011) & Prioritizing strategies \\
\cline { 2 - 3 } & Zavadskas et al. (2011a) & Enterprises management \\
\cline { 2 - 3 } & Zavadskas et al. (2012) & Selecting a project manager \\
\hline COPRAS & Chatterjee et al. (2011) & Material selection based on COPRAS and \\
& & EVAMIX methods \\
\cline { 2 - 3 } & Podvezko (2011) & Comparative analysis of MCDM methods \\
& Zavadskas et al. (2011b) & Assessment of the indoor environment \\
\cline { 2 - 3 } COPRAS-G & Hashemkhani Zolfani et al. (2011) & Locating forest roads \\
\cline { 2 - 3 } & Chatterjee and Chakraborty (2012) & Using COPRAS-G method \\
\hline
\end{tabular}

The calculation steps of AHP are as follows (Saaty 1990):

The first step is structuring a problem as hierarchy.

The second step is the elicitation of a judgment on pair wise comparison.

The third step is establishing the composite or global priorities of alternatives.

The procedure of applying the COPRAS-G method consists of the following steps (Zavadskas et al. 2009):

1. Selecting the set of the most important criteria describing alternatives.

2. Constructing decision-making matrix $\otimes X$ :

$\otimes X=\left[\begin{array}{cccc}{\left[\otimes x_{11}\right]} & {\left[\otimes x_{12}\right]} & \cdots & {\left[\otimes x_{1 m}\right]} \\ {\left[\otimes x_{21}\right]} & {\left[\otimes x_{22}\right]} & \cdots & {\left[\otimes x_{1 m}\right]} \\ \vdots & \vdots & \ddots & \vdots \\ {\left[\otimes x_{n 1}\right]} & {\left[\otimes x_{n 2}\right]} & \cdots & {\left[\otimes x_{n m}\right]}\end{array}\right]=\left[\begin{array}{cccc}{\left[\underline{x}_{11} ; \bar{x}_{11}\right]} & {\left[\underline{x}_{12} ; \bar{x}_{12}\right]} & \cdots & {\left[\underline{x}_{1 m} ; \bar{x}_{1 m}\right]} \\ {\left[\underline{x}_{21} ; \bar{x}_{21}\right]} & {\left[\underline{x}_{22} ; \bar{x}_{22}\right]} & \cdots & {\left[\underline{x}_{2 m} ; \bar{x}_{1 m}\right]} \\ \vdots & \vdots & \ddots & \vdots \\ {\left[\underline{x}_{n 1} ; \bar{x}_{n 1}\right]} & {\left[\underline{x}_{n 2} ; \bar{x}_{n 2}\right]} & \cdots & {\left[\underline{x}_{n m} ; \bar{x}_{n m}\right]}\end{array}\right] ; j=\overline{1, n} ; i=\overline{1, m}$,

where $\otimes x_{j i}$ is determined by $\underline{x}_{j i}$ (lowest value, lower limit) and $\bar{x}_{j i}$ (highest value, higher limit).

3. Determining the significance of criteria $q_{i}$.

4. Normalized values of decision-making matrix $\otimes X$ are calculated applying formula 2 :

$$
\begin{aligned}
& \underline{x}_{j i}=\frac{\underline{x}_{j i}}{\frac{1}{2}\left(\sum_{j=1}^{n} \underline{x}_{j i}+\sum_{j=1}^{n} \bar{x}_{j i}\right)}=\frac{2 \underline{x}_{j i}}{\left(\sum_{j=1}^{n} \underline{x}_{j i}+\sum_{j=1}^{n} \bar{x}_{j i}\right)}, \bar{x}_{j i}=\frac{\bar{x}_{j i}}{\frac{1}{2}\left(\sum_{j=1}^{n} \underline{x}_{j i}+\sum_{j=1}^{n} \bar{x}_{j i}\right)}=\frac{2 \bar{x}_{j i}}{\left(\sum_{j=1}^{n} \underline{x}_{j i}+\sum_{j=1}^{n} \bar{x}_{j i}\right)} ; \\
& j=\overline{1, n} ; \quad i=\overline{1, m},
\end{aligned}
$$


where $\underline{x}_{j i}$ is a lower value of criterion $i$ in alternative $j$ of the achieved solution; $\bar{x}_{j i}$ is a higher value of criterion $i$ in alternative $j$ of the achieved solution; $m$ is the number of criteria; $n$ is the number of compared alternatives.

The decision-making matrix is normalized applying Formula 3:

$$
\otimes \tilde{X}=\left[\begin{array}{cccc}
{\left[\underline{\tilde{x}}_{11} ; \tilde{\overline{\bar{x}}}_{11}\right]} & {\left[\underline{\tilde{x}}_{12} ; \tilde{\overline{\bar{x}}}_{12}\right]} & \cdots & {\left[\underline{\tilde{x}}_{1 m} ; \tilde{\overline{\bar{x}}}_{1 m}\right]} \\
{\left[\underline{\tilde{x}}_{21} ; \tilde{\bar{x}}_{21}\right]} & {\left[\underline{\tilde{x}}_{22} ; \tilde{\bar{x}}_{22}\right]} & \cdots & {\left[\underline{\tilde{x}}_{2 m} ; \tilde{\bar{x}}_{1 m}\right]} \\
\vdots & \vdots & \ddots & \vdots \\
{\left[\underline{\tilde{x}}_{n 1} ; \tilde{\bar{x}}_{n 1}\right]} & {\left[\underline{\tilde{x}}_{n 2} ; \tilde{\bar{x}}_{n 2}\right]} & \cdots & {\left[\underline{\tilde{x}}_{n m} ; \tilde{\bar{x}}_{n m}\right]}
\end{array}\right]
$$

5. When calculating the weighted normalized decision matrix $\otimes \hat{X}$, the weighted normalized values $\otimes \hat{x}_{j i}$ are calculated as follows:

$$
\otimes \hat{x}_{j i}=\otimes \tilde{x}_{j i} \cdot q_{i} ; \text { or } \underline{\hat{x}}_{j i}=\underline{\tilde{x}}_{j i} \cdot q_{i} \text { and } \tilde{\bar{x}}_{j i}=\tilde{\bar{x}}_{j i} \cdot q_{i},
$$

where $q_{i}$ is the significance of the $i$-th criterion. Then, the weighted normalized decisionmaking matrix $\otimes \hat{X}$ is

$$
\otimes \hat{X}=\left[\begin{array}{cccc}
{\left[\otimes \hat{x}_{11}\right]} & {\left[\otimes \hat{x}_{12}\right]} & \cdots & {\left[\otimes \hat{x}_{1 m}\right]} \\
{\left[\otimes \hat{x}_{21}\right]} & {\left[\otimes \hat{x}_{22}\right]} & \cdots & {\left[\otimes \hat{x}_{1 m}\right]} \\
\vdots & \vdots & \ddots & \vdots \\
{\left[\otimes \hat{x}_{n 1}\right]} & {\left[\otimes \hat{x}_{n 2}\right]} & \cdots & {\left[\otimes \hat{x}_{n m}\right]}
\end{array}\right]=\left[\begin{array}{cccc}
{\left[\underline{\hat{x}}_{11} ; \hat{\bar{x}}_{11}\right]} & {\left[\underline{\hat{x}}_{12} ; \hat{\bar{x}}_{12}\right]} & \cdots & {\left[\underline{\hat{x}}_{1 m} ; \hat{\bar{x}}_{1 m}\right]} \\
{\left[\underline{\hat{x}}_{21} ; \hat{\bar{x}}_{21}\right]} & {\left[\underline{\hat{x}}_{22} ; \hat{\bar{x}}_{22}\right]} & \cdots & {\left[\underline{\hat{x}}_{2 m} ; \hat{\bar{x}}_{2 m}\right]} \\
\vdots & \vdots & \ddots & \vdots \\
{\left[\underline{\hat{x}}_{n 1} ; \hat{\bar{x}}_{n 1}\right]} & {\left[\underline{\hat{x}}_{n 2} ; \hat{\bar{x}}_{n 2}\right]} & \cdots & {\left[\underline{\hat{x}}_{n m} ; \hat{\bar{x}}_{n m}\right]}
\end{array}\right] .
$$

6. When calculating the sums $P_{j}$ of criterion values, higher values are more preferable:

$$
P_{j}=\frac{1}{2} \sum_{i=1}^{k}\left(\underline{\hat{x}}_{j i}+\hat{\bar{x}}_{j i}\right),
$$

where $k$ is the number of attributes to be maximized.

7. Calculating the sums $R_{j}$ of attribute values, lower values are more preferable:

$$
R_{j}=\frac{1}{2} \sum_{i=k+1}^{m}\left(\underline{\hat{x}}_{j i}+\hat{\bar{x}}_{j i}\right) ; i=\overline{k, m},
$$

where $(m-k)$ is the number of attributes to be minimized.

8. Calculating the relative significance of each alternatively $Q_{j}$, the expression is as follows:

$$
Q_{j}=P_{j}+\frac{\sum_{j=1}^{n} R_{j}}{R_{j} \sum_{j=1}^{n} \frac{1}{R_{j}}} .
$$

9. The optimally criterion by $K$ is calculated by applying the formula:

$$
K=\max _{j} Q_{j}, \quad j=\overline{1, n} \text {. }
$$


10. For calculating the utility degree of each alternative, the formula is as follows:

$$
N_{j}=\frac{Q_{j}}{Q_{\max }} \times 100 \%,
$$

where $Q_{j}$ and $Q_{\max }$ are the relative significance of alternatives obtained from Equation (8).

11. When applying the calculation results of $N_{j}$ the order of alternative priority is constructed.

\section{A case study: selecting a supplier company}

The aim of this case study is to utilize a new hybrid model of MCDM methods for selecting a supplier. A case company for selecting a supplier is Kalleh Company, the oldest and most famous company producing disposable containers in Iran.

\subsection{Selecting criteria and survey data}

Kalleh Company tends to select one supplier among three partners. As highlighted previously, eight evaluation criteria are used.

Criteria for selecting a supplier include:

$$
\begin{aligned}
& \otimes x_{1} \text { - cost; } \\
& \otimes x_{2} \text { - quality; } \\
& \otimes x_{3} \text { - distance; } \\
& \otimes x_{4} \text { - delivery reliability; } \\
& \otimes x_{5} \text { - reputation; } \\
& \otimes x_{6} \text { - technology level; } \\
& \otimes x_{7} \text { - compatibility; } \\
& \otimes x_{8} \text { - development ability. }
\end{aligned}
$$

Based on the nature of eight criteria for evaluation, optimization directions for each criterion are determined as follows:

$$
\begin{aligned}
& \otimes x_{2,4,5,6,7,8} \underset{\text { optimal direction (max) }}{\longrightarrow} \\
& \otimes x_{1,3} \underset{\text { optimal direction }(\mathrm{min})}{\longrightarrow}
\end{aligned}
$$

Then, a questionnaire was sent to a group of 10 senior experts the majority of which have been working in the companies producing disposable containers for at least six years. All of 10 questionnaires have been finally determined to be utilized for this study with a total response rate of $100 \%$. Demographic information is provided in Table 3.70 per cent of the respondents are males. More than a half (60\%) of the surveyed participants are between 31 and 40 years of age. $60 \%$ of the respondents have served between 6 and 10 years and about $30 \%$ - under 5 years. $50 \%$ of the respondents are BA graduates and $100 \%$ of those have industrial background. Their ratings adopted the ratio scale as given in Table 1 with respect to the importance of evaluation criteria; ratings used a range of $0-100$ with regard to the initial decision-making matrix $\otimes X$. 
Table 3. Demographic information

\begin{tabular}{|c|c|c|c|c|c|c|c|}
\hline Variable & Items & $N$ & Percentage & Variable & Items & $N$ & Percentage \\
\hline \multirow[t]{2}{*}{ 1. Sex } & (1) Male & 7 & $70 \%$ & \multirow{4}{*}{$\begin{array}{l}\text { 4. Education } \\
\text { background }\end{array}$} & (1) Vocational & 0 & $0 \%$ \\
\hline & (2) Female & 3 & $30 \%$ & & (2) Bachelor & 5 & $50 \%$ \\
\hline \multirow[t]{5}{*}{ 2. Age } & (1) Under 30 & 2 & $20 \%$ & & (3) Master & 4 & $40 \%$ \\
\hline & (2) $31-40$ & 6 & $60 \%$ & & (4) Doctoral & 1 & $10 \%$ \\
\hline & (3) $41-50$ & 2 & $20 \%$ & \multirow{3}{*}{$\begin{array}{l}\text { 5. Occupational } \\
\text { background }\end{array}$} & (1) Academic & 0 & $0 \%$ \\
\hline & (4) Above 51 & 0 & $0 \%$ & & (2) Industrial & 10 & $100 \%$ \\
\hline & & & & & (3) Governmental & 0 & $0 \%$ \\
\hline \multirow{4}{*}{$\begin{array}{l}\text { 3. Service } \\
\text { tenure }\end{array}$} & (1) Under 5 & 3 & $30 \%$ & & & & \\
\hline & (2) 6-10 & 6 & $60 \%$ & & & & \\
\hline & (3) $11-20$ & 1 & $10 \%$ & & & & \\
\hline & (4) Above 21 & 0 & $0 \%$ & & & & \\
\hline
\end{tabular}

\subsection{Selection of the best supplier}

After summarizing the opinions of senior experts and following the steps of AHP, the weights of evaluation criteria are provided in Table 4. The table also indicates the initial decisionmaking matrix $\otimes X$ and the values of evaluation criteria are described in intervals. The initial decision-making matrix $\otimes X$ has been normalized and weighted initially and the obtained result $(\otimes \hat{X})$ is provided in Table 5 . In accordance with the steps of COPRAS-G, the evaluation of three suppliers is computed and ranking suppliers for Kalleh Company is finally discovered (Table 6).

Table 4. The initial decision-making matrix and the values of evaluation criteria described in intervals

\begin{tabular}{cccccc}
\hline Criterion & Optimal & Weights & \multicolumn{3}{c}{ Initial decision making matrix } \\
\cline { 3 - 6 } & & & \multicolumn{3}{c}{ Supplier } \\
\cline { 3 - 6 } & & & $S_{1}$ & $S_{2}$ & $S_{3}$ \\
\hline$\otimes x_{1}$ & $\min$ & 0.160 & {$[60 ; 70]$} & {$[80 ; 90]$} & {$[40 ; 60]$} \\
\hline$\otimes x_{2}$ & $\max$ & 0.158 & {$[70 ; 80]$} & {$[90 ; 95]$} & {$[60 ; 70]$} \\
\hline$\otimes x_{3}$ & $\min$ & 0.060 & {$[80 ; 90]$} & {$[70 ; 80]$} & {$[40 ; 60]$} \\
\hline$\otimes x_{4}$ & $\max$ & 0.150 & {$[90 ; 95]$} & {$[80 ; 90]$} & {$[70 ; 80]$} \\
\hline$\otimes x_{5}$ & $\max$ & 0.135 & {$[40 ; 60]$} & {$[60 ; 70]$} & {$[70 ; 80]$} \\
\hline$\otimes x_{6}$ & $\max$ & 0.178 & {$[60 ; 70]$} & {$[80 ; 90]$} & {$[70 ; 80]$} \\
\hline$\otimes x_{7}$ & $\max$ & 0.045 & {$[80 ; 90]$} & {$[70 ; 80]$} & {$[60 ; 70]$} \\
\hline$\otimes x_{8}$ & $\max$ & 0.114 & {$[70 ; 80]$} & {$[90 ; 95]$} & {$[80 ; 90]$} \\
\hline & & $q_{i}=1$ & & & \\
\hline
\end{tabular}


Table 5. Normalized and weighted-normalized decision-making matrix and the values of evaluation criteria described in intervals

\begin{tabular}{|c|c|c|c|c|c|c|}
\hline \multirow[t]{3}{*}{ Criterion } & \multicolumn{3}{|c|}{$\begin{array}{l}\text { Normalized decision } \\
\text { making matrix }\end{array}$} & \multicolumn{3}{|c|}{$\begin{array}{l}\text { Weighted-normalized decision } \\
\text { making matrix }\end{array}$} \\
\hline & \multicolumn{3}{|c|}{ Supplier } & \multicolumn{3}{|c|}{ Supplier } \\
\hline & $S_{1}$ & $S_{2}$ & $S_{3}$ & $S_{1}$ & $S_{2}$ & $S_{3}$ \\
\hline$\underline{\hat{x}}_{1 n} ; \hat{\bar{x}}_{1 n}$ & $\begin{array}{l}{[0.300 ;} \\
0.350]\end{array}$ & $\begin{array}{l}{[0.400} \\
0.450]\end{array}$ & $\begin{array}{l}{[0,200 ;} \\
0,300]\end{array}$ & $\begin{array}{l}{[0.048 ;} \\
0.056]\end{array}$ & $\begin{array}{l}{[0.064} \\
0.072]\end{array}$ & $\begin{array}{l}{[0.032 ;} \\
0.048]\end{array}$ \\
\hline$\underline{\hat{x}}_{2 n} ; \hat{\bar{x}}_{2 n}$ & $\begin{array}{l}{[0.297 ;} \\
0.342]\end{array}$ & $\begin{array}{l}{[0.386 ;} \\
0.405]\end{array}$ & $\begin{array}{l}{[0,253 ;} \\
0,297]\end{array}$ & $\begin{array}{l}{[0.047 ;} \\
0.054]\end{array}$ & $\begin{array}{l}{[0.061 ;} \\
0.064]\end{array}$ & $\begin{array}{l}{[0.040 ;} \\
0.047]\end{array}$ \\
\hline$\underline{\hat{x}}_{3 n} ; \hat{\bar{x}}_{3 n}$ & $\begin{array}{l}{[0.367 ;} \\
0.417]\end{array}$ & $\begin{array}{l}{[0.333 ;} \\
0.367]\end{array}$ & $\begin{array}{l}{[0,183 ;} \\
0,283]\end{array}$ & $\begin{array}{l}{[0.022 ;} \\
0.025]\end{array}$ & $\begin{array}{l}{[0.020} \\
0.022]\end{array}$ & $\begin{array}{l}{[0.011 ;} \\
0.017]\end{array}$ \\
\hline$\underline{\hat{x}}_{4 n} ; \overline{\bar{x}}_{4 n}$ & $\begin{array}{l}{[0.353 ;} \\
0.373]\end{array}$ & $\begin{array}{l}{[0.313 ;} \\
0.353]\end{array}$ & $\begin{array}{l}{[0,273 ;} \\
0,313]\end{array}$ & $\begin{array}{l}{[0.053 ;} \\
0.056]\end{array}$ & $\begin{array}{l}{[0.047} \\
0.053]\end{array}$ & $\begin{array}{l}{[0.041 ;} \\
0.047]\end{array}$ \\
\hline$\underline{\hat{x}}_{5 n} ; \hat{\bar{x}}_{5 n}$ & $\begin{array}{l}{[0.207 ;} \\
0.311]\end{array}$ & $\begin{array}{l}{[0.311 ;} \\
0.363]\end{array}$ & $\begin{array}{l}{[0,363 ;} \\
0,415]\end{array}$ & $\begin{array}{l}{[0.028 ;} \\
0.042]\end{array}$ & $\begin{array}{l}{[0.042 ;} \\
0.049]\end{array}$ & $\begin{array}{l}{[0.049 ;} \\
0.056]\end{array}$ \\
\hline$\underline{\hat{x}}_{6 n} ; \hat{\bar{x}}_{6 n}$ & $\begin{array}{l}{[0.264 ;} \\
0.309]\end{array}$ & $\begin{array}{l}{[0.354 ;} \\
0.399]\end{array}$ & $\begin{array}{l}{[0,309} \\
0,354]\end{array}$ & $\begin{array}{l}{[0.047 ;} \\
0.055]\end{array}$ & $\begin{array}{l}{[0.063 ;} \\
0.071]\end{array}$ & $\begin{array}{l}{[0.055 ;} \\
0.063]\end{array}$ \\
\hline$\underline{\hat{x}}_{7 n} ; \hat{\bar{x}}_{7 n}$ & $\begin{array}{l}{[0.356 ;} \\
0.400]\end{array}$ & $\begin{array}{l}{[0.311 ;} \\
0.356]\end{array}$ & $\begin{array}{l}{[0,267 ;} \\
0,311]\end{array}$ & $\begin{array}{l}{[0.016 ;} \\
0.018]\end{array}$ & $\begin{array}{l}{[0.014} \\
0.016]\end{array}$ & $\begin{array}{l}{[0.012 ;} \\
0.014]\end{array}$ \\
\hline$\underline{\hat{x}}_{8 n} ; \hat{\bar{x}}_{8 n}$ & $\begin{array}{l}{[0.272 ;} \\
0.316]\end{array}$ & $\begin{array}{l}{[0.351 ;} \\
0.368]\end{array}$ & $\begin{array}{l}{[0,316 ;} \\
0,351]\end{array}$ & $\begin{array}{l}{[0.031 ;} \\
0.036]\end{array}$ & $\begin{array}{c}{[0.040 ;} \\
0.042]\end{array}$ & $\begin{array}{l}{[0.036 ;} \\
0.040]\end{array}$ \\
\hline
\end{tabular}

Table 6. Evaluation of utility degree

\begin{tabular}{cccc}
\hline Supplier & $S_{1}$ & $S_{2}$ & $S_{3}$ \\
\hline$P_{j}$ & 0.249 & 0.281 & 0.25 \\
\hline$R_{j}$ & 0.075 & 0.094 & 0.054 \\
\hline$Q_{j}$ & 0.318 & 0.336 & 0.347 \\
\hline$N_{j}$ & $91.64 \%$ & $96.82 \%$ & $100 \%$ \\
\hline
\end{tabular}

The weights of the criteria were determined applying the AHP method. The assessment results of alternatives are presented in Table 6. Ranking alternatives applying AHP and COPRAS-G methods are presented in Tables 5 and 6 . Specifically, according to $N_{j}$, ranking obtained in the procedure of supplier selection is as follows: Supplier ${ }_{3} \succ$ Supplier $_{2} \succ$ Supplier $_{1}$. It is advised that the supplier corresponding to the highest utility degree should be selected as the best one (e.g. Supplier ${ }_{3}$ ). The overall results of the COPRAS-G method and ranking are summarized in Table 6. 


\section{Generalization}

Dynamic business environments lead to selecting the best suppliers that are very important for companies. The model of supplier selection is the foundation of supply chain cooperation that seems to be a MCDM problem involving numerous tasks (evaluation criteria).

The paper has developed a hybrid model of the MCDM method. The proposed model consists of AHP for weighing eight evaluation criteria and the COPRAS-G method for evaluating performance. Research focuses on the problem of selecting a supply company at the national and international level. The proposed SCM model can also be a guide to other foreign companies efficiently selecting their suppliers for the decision-making process.

On the basis of calculated results of AHP and COPRAS-G methods, the best supplier for Kalleh Company has been verified. By applying calculation results, ranking obtained in the procedure of supplier selection is as follows: Supplier ${ }_{3} \succ$ Supplier $_{2} \succ$ Supplier $_{1}$.

\section{References}

Amid, A.; Ghodsypour, S. H. 2006. Fuzzy multi objective linear model for supplier selection in a supply chain, Production Economics 104: 394-407. http://dx.doi.org/10.1016/j.ijpe.2005.04.012

Angelou, G. N.; Economides, A. A. 2009. A compound real option and AHP methodology for evaluating ICT business alternatives, Telematics and Informatics 26(4): 353-374. http://dx.doi.org/10.1016/j.tele.2008.02.004

Baležentis, A.; Baležentis, T. 2011. An innovative multi-criteria supplier selection based on two-tuple MULTIMOORA and hybrid data, Economic Computation and Economic Cybernetics Studies and Research 45(2): 37-56.

Chatterjee, P.; Athawale, V. M.; Chakraborty, S. 2011. Materials selection using complex proportional assessment and evaluation of mixed data methods, Materials \& Design 32(2): 851-860. http://dx.doi.org/10.1016/j.matdes.2010.07.010

Chatterjee, P.; Chakraborty, S. 2012. Material selection using preferential ranking methods, Materials \& Design 35: 384-393. http://dx.doi.org/10.1016/j.matdes.2011.09.027

Chen, M. K.; Wang, S. C. 2010. The critical factors of success for information service industry in developing international market: using analytic hierarchy process (AHP) approach, Expert Systems with Applications 37(1): 694-704. http://dx.doi.org/10.1016/j.eswa.2009.06.012

Christopher, M. 1998. Logistics and Supply Chain Management. London: Pitman Publishing.

Datta, S.; Beriha, G. S.; Patnaik, B.; Mahapatra, S. S. 2009. Use of compromise ranking method for supervisor selection: a multi-criteria decision making (MCDM) approach, International Journal of Vocational and Technical Education 1: 7-13.

Deng, J. L. 1982. Control problems of Grey system, Systems and Control Letters 1(5): 288-294. http://dx.doi.org/10.1016/S0167-6911(82)80025-X

Ellram, L. M.; Cooper, M. C. 1990. Supply chain management, partnerships, and the shipper: third party relationship, International Journal of Logistics Management 1(2): 1-10. http://dx.doi.org/10.1108/95740939080001276

Florez-Lopez, R. 2007. Strategic supplier selection in the added-value perspective: a CI approach, Information Sciences 177(5): 1169-1179. http://dx.doi.org/10.1016/j.ins.2006.08.009

Fouladgar, M. M.; Yazdani-Chamzini, A.; Zavadskas, E. K. 2011. An integrated model for prioritizing strategies of the Iranian mining sector, Technological and Economic Development of Economy 17(3): 459-483. http://dx.doi.org/10.3846/20294913.2011.603173 
Hashemkhani Zolfani, S.; Rezaeiniya, N.; Zavadskas, E. K.; Turskis, Z. 2011. Forest roads locating based on AHP and COPRAS-G methods: an empirical study based on Iran, $E \& M$ : Ekonomie a Management 14(4): 6-21.

Lam, K.-C.; Tao, R.; Lam, M. C.-K. 2010. A material supplier selection model for property developers using Fuzzy Principal Component Analysis, Automation in Construction 19(5): 608-618. http://dx.doi.org/10.1016/j.autcon.2010.02.007

Liberatore, M. J.; Nydick, R. L. 2008. The analytic hierarchy process in medical and health care decision making: a literature review, European Journal of Operational Research 89(1): 194-207. http://dx.doi.org/10.1016/j.ejor.2007.05.001

Lijuan, M. 2002. The primary study of supplier selection based on supply chain management, Industrial Engineering Management 6: 23-25.

Lummus, R. R.; Vokurka, R. J. 1999. Defining supply chain management: a historical perspective and practical guidelines, Industrial Management \& Data Systems 99(1): 11-17. http://dx.doi.org/10.1108/02635579910243851

Madhuri, Ch. B.; Chandulal, J. A. 2010. Evaluating web sites using COPRAS GRA Combined with Grey clustering, International Journal of Engineering Science and Technology 2(10): 5280-5294.

Medineckiene, M.; Turskis, Z.; Zavadskas, E. K. 2010. Sustainable construction taking into account the building impact on the environment, Journal of Environmental Engineering and Landscape Management 18(2): 118-127. http://dx.doi.org/10.3846/jeelm.2010.14

Podvezko, V. 2011. The comparative analysis of MCDA methods SAW and COPRAS, Inzinerine Ekonomika - Engineering Economics 22(2): 134-146.

Podvezko, V.; Mitkus, S.; Trinkuniene, E. 2010. Complex evaluation of contracts for construction, Journal of Civil Engineering and Management 16(2): 287-297. http://dx.doi.org/10.3846/jcem.2010.33

Quayle, M. 2003. A study of supply chain management practice in UK industrial SMEs, Supply Chain Management: an International Journal 8(1): 79-86. http://dx.doi.org/10.1108/13598540310463387

Saaty, T. L. 1990. How to make a decision: the analytic hierarchy process, European Journal of Operation Research 48(1): 9-26. http://dx.doi.org/10.1016/0377-2217(90)90057-I

Shihua, M.; Xubin, W. 2002. A method of confirming the weight of attributes for supplier evaluation, Industrial Engineering Management 6: 5-8.

Shiromaru, I. 2000. A fuzzy satisfying method for electric power plant coal purchase using genetic algorithms, Operational Research 126(1): 218-230. http://dx.doi.org/10.1016/S0377-2217(99)00293-3

Shuyong, K.; Rongqiu, C. 1998. The relationship of manufacturers and suppliers under JIT, Journal of Management Engineering 3: 46-51.

Sivilevicius, H. 2011a. Modelling the interaction of transport system elements, Transport 26(1): 20-34. http://dx.doi.org/10.3846/16484142.2011.560366

Sivilevicius, H. 2011b. Application of expert evaluation method to determine the importance of operating asphalt mixing plant quality criteria and rank correlation, Baltic Journal of Road and Bridge Engineering 6(1): 48-58. http://dx.doi.org/10.3846/bjrbe.2011.07

Turskis, Z.; Zavadskas, E. K. 2010. A novel method for multiple criteria analysis: grey additive ratio assessment (ARAS-G) method, Informatica 21(4): 597-610.

Ustun, O.; Demirtas, E. A. 2008. Multi-period lot-sizing with supplier selection using achievement scalarizing functions, Computers and Industrial Engineering 54(4): 918-931. http://dx.doi.org/10.1016/j.cie.2007.10.021

Wang, J. W.; Guo, S. W. 2007. Research of construction supplier selection model based on grey relevancy, Journal of WUHAN University of Technology 29(3): 153-156. 
Wang, H. S. 2008. Configuration change assessment: genetic optimization approach with fuzzy multiple criteria for part supplier selection decisions, Expert Systems with Applications 34(2): 1541-1555. http://dx.doi.org/10.1016/j.eswa.2007.01.020

Xia, W.; Wu, Z. 2007. Supplier selection with multiple criteria in volume discount environments, Omega 35(5): 494-504. http://dx.doi.org/10.1016/j.omega.2005.09.002

Xu, J.; Li, B.; Wu, D. 2009. Rough data envelopment analysis and its application to supply chain performance evaluation, International Journal of Production Economics 122(2): 628-638. http://dx.doi.org/10.1016/j.ijpe.2009.06.026

Zavadskas, E. K.; Vainiūnas, P.; Turskis, Z.; Tamošaitienè, J. 2012. Multiple criteria decision support system for assessment of projects managers in construction, International Journal of Information Technology \& Decision Making 11(2): 501-520. http://dx.doi.org/10.1142/S0219622012400135

Zavadskas, E. K.; Turskis, Z.; Tamosaitiene, J. 2011a. Selection of construction enterprises management strategy based on the SWOT and multi-criteria analysis, Archives of Civil and Mechanical Engineering Wroclaw 11(4): 1063-1082.

Zavadskas, E. K.; Kaklauskas, A.; Turskis, Z.; Tamosaitiene, J.; Kalibatas, D. 2011b. Assessment of the indoor environment of dwelling houses by applying the COPRAS-G method: Lithuania case study, Environmental Engineering and Management Journal 10(5): 637-647.

Zavadskas, E. K.; Turskis, Z. 2010. A new additive ratio assessment (ARAS) method in multicriteria decision-making, Technological and Economic Development of Economy 16(2): 159-172. http://dx.doi.org/10.3846/tede.2010.10

Zavadskas, E. K.; Turskis, Z.; Tamošaitienė, J. 2010a. Risk assessment of construction projects, Journal of Civil Engineering and Management 16(1): 33-46. http://dx.doi.org/10.3846/jcem.2010.03

Zavadskas, E. K.; Turskis, Z.; Vilutiene, T. 2010b. Multiple criteria analysis of foundation instalment alternatives by applying additive ratio assessment (ARAS) method, Archives of Civil and Mechanical Engineering 10(3): 123-141. http://dx.doi.org/10.1016/S1644-9665(12)60141-1

Zavadskas, E. K.; Kaklauskas, A.; Turskis, Z.; Tamosaitiene, J. 2009. Multi-attribute decision-making model by applying grey numbers, Informatica 20(2): 305-320.

Zavadskas, E. K.; Kaklauskas, A.; Turskis, Z.; Tamošaitienė, J. 2008a. Selection of the effective dwelling house walls by applying attributes values determined at intervals, Journal of Civil Engineering and Management 14(2): 85-93. http://dx.doi.org/10.3846/1392-3730.2008.14.3

Zavadskas, E. K.; Turskis, Z.; Tamosaitiene, J.; Marina, V. 2008b. Multicriteria selection of project managers by applying grey criteria, Technological and Economic Development of Economy 14(4): 462-477. http://dx.doi.org/10.3846/1392-8619.2008.14.462-477

Zavadskas, E. K.; Kaklauskas, A. 1996. Multiple Criteria Evaluation of Buildings. Vilnius: Technika.

Zhu, J. 2004. A buyer-seller game model for selection and negotiation of purchasing bids: extension and new models, European Journal of Operational Research 154: 150-156.

http://dx.doi.org/10.1016/S0377-2217(02)00697-5

Sarfaraz HASHEMKHANI ZOLFANI. B.Sc. in Industrial Management from Shomal University of Amol, Iran. M.Sc. in Industrial Engineering-System Management and Productivity from Shomal University. Works at the Research Institute of the Internet and Intelligent Technologies, Vilnius Gediminas Technical University. The member of EURO Working Group OR in Sustainable Development and Civil Engineering. The author of more than 40 scientific papers presented, published or reviewed at/for International Conferences and Journals (including ISI-cited publications). Research interests: performance evaluation, strategic management, decision-making theory, supply chain management, (fuzzy) multi-criteria decision making and marketing. 
I-Shuo CHEN. Perusing PhD in Business at Trinity College Dublin, Ireland. Tutor of organizational behaviour at Trinity College Dublin, Ireland. A reviewer of journals, including Journal of Operational Research Society, International Journal of Information Technology \& Decision Making, Knowledge-Based Systems, Applied Soft Computing, Annals of Operations Research, African Journal of Business Management, Social Behaviour and Personality, etc. Research interests: creativity, organizational innovation, organizational behaviour, vision, performance systems and evaluation, TQM and (Fuzzy) MCDM. The articles have been published in several high level peer reviewed journals (including ISI-cited publications).

Nahid REZAEINIYA. B.Sc. in Industrial Engineering from Shomal University of Amol, Iran. M.Sc in Industrial Engineering - planning program of economic and social systems from Alghadir Institute of higher education, Tabriz, Iran (2009-2011). The author of 15 scientific papers. Research interests: performance evaluation, (fuzzy) multi criteria decision making, decision-making theory and quality management. Part time teacher at Islamic Azad University.

Jolanta TAMOŠAITIENĖ. PhD, Assoc. Prof. and Vice-Dean of the Department of Construction Technology and Management at the Faculty of Civil Engineering, Vilnius Gediminas Technical University, Lithuania. The member of EURO Working Group OR in Sustainable Development and Civil Engineering. The author of more than 50 scientific papers presented, published or reviewed at/for International Conferences and Journals (including ISI-cited publications). Research interests: construction technology and organization, strategic management, supply chain management, administration of construction projects, decision-making and grey theory. 